\title{
A Modified Counting Method for Very Small Number of Residual White Blood Cells in Platelet Concentrates by Flow Cytometory
}

\author{
Mitsunobu Tanaka, Taiko Seno, Noriko Okuni, Hirotoshi Shibata, \\ Yoshio Kobayashi, Yasuto Okubo, Hideo Yamaguchi \\ Osaka Red Cross Blood Center, First Research Division, 2-4-43 Morinomiya Joto-ku, \\ Osaka, 536, Japan
}

(平成 8 年 6 月 21 日受付)

(平成 9 年 1 月13日受理)

\begin{abstract}
フローサイトメトリーによる血小板製剤に残存する 微量白血数測定法の改良
\end{abstract}

\begin{tabular}{|c|c|c|c|}
\hline 光信 & 瀬尾たい子 & 大國 & 典子 \\
\hline 芳夫 & 大久保康人 & 山口 & 英夫 \\
\hline
\end{tabular}

濃厚血小板製剤（PC）中の微量白血球混入量をフローサイトメトリー (FCM) で測定する方法は すでに多く報告されている。我々は，非標識のニワトリ血球 (cRBC) を内部標準として試料と同時 に PI 染色し，Cytoron（オーソ・クリニカル・ダイアグノスティクス K.K.）を使用して細胞数を測 定する方法を開発した。この方法で測定できる細胞数は $1.6 \times 10^{2}-10^{5}$ 個 $/ \mathrm{m} l$ であり，非常に再現性も 良く，従来の方法に比べて操作が簡単で短時間で測定できる.

また，測定に必要な検体量は $0.2 \mathrm{~m} l$ と少なく，濃厚血小板製剤（PC）に混入する微量白血球数を 測定するために有効な方法であり，製品管理に役立つと考えられる.

Key Words: white blood cell depletion, reduced WBC in blood component, residual WBC counting.

\section{Summary}

A modified flow cytometric (FCM) method for counting very small numbers of residual white blood cells (WBCs) in platelet concentrates (PCs) was developed. Non-labeled chicken red blood cells (cRBCs) were added to samples of PCs as an internal control. After incubation with propidium iodide (PI) staining agent, residual WBCs and control cRBCs were counted using a Cytoron flow cytometer (OrthoClinical Diagnostics K.K. Tokyo, Japan). Average time needed to count one sample was 40 seconds. The range of cell numbers able to counted by this method was $1.6 \times 10^{2}-10^{5}$ cells per $\mathrm{m} l$ with good reproducibility.

The advantages of this technique are that its rapid and accurate, requires only $0.2 \mathrm{~m} l$ of $\mathrm{PCs}$ and is easy to perform. It therefore represents a useful method for quality control of residual WBCs in platelet concentrates.

\section{Introduction}

White blood cell (WBC)-reduced PCs may diminish the risk of graft versus host disease (GVHD), sensitization to WBC antigens and viral transmission. As newer WBC filters are developed, methods for counting residual WBCs 
in PCs become crucial. Various WBC counting techniques have been developed and published ${ }^{1) \sim 5)}$. Vachula et $\mathrm{al}^{5)}$ recently reported a method using flow cytometry (FCM), in which they added a known amount of fluorescein (FITC)-labeled chicken red blood cells (cRBCs) to samples of PCs, stained the mixture with PI reagent, and then counted the number of WBCs using a two-color flow cytometer.

Although this technique is accurate, it is not easy to perform, since the FITC-labeled cRBCs are unstable, and the intensity of FITC decreases over time. When this occurrs, there is no clear separation between $\mathrm{cRBC}$ s and WBCs on FCM pattern.

We describe a modified technique using cRBCs not pre-labeled with FITC as the internal indicator. A known amount of unlabeled cRBCs were added to PCs samples, then stained with PI reagent. All cells were counted using a single color detector by FCM and the distinction between WBCs and cRBCs was clear in terms of the peak channel of red fluorescence.

This method was easy to perform and proved to be useful for the routine quality control testing of PCs for residual WBCs.

\section{Materials and Methods}

Collection of PCs:

PCs from normal blood donors were prepared using Cobe Spectra (Cobe Lab. K.K.) or CS-3000 plus (Baxter Healthcare Corp. IL., USA) instruments.

Preparation of PI reagent:

PI reagent was prepared by mixing $1 \mathrm{ml}$ of Triton-X 100, $100 \mathrm{mg}$ of sodium citrate, $500 \mathrm{U}$ of RNAase (Sigma Chemical Corp., USA) and 0.1 $\mathrm{m} l$ of ethanol containing $5 \mathrm{mg}$ propidium iodide

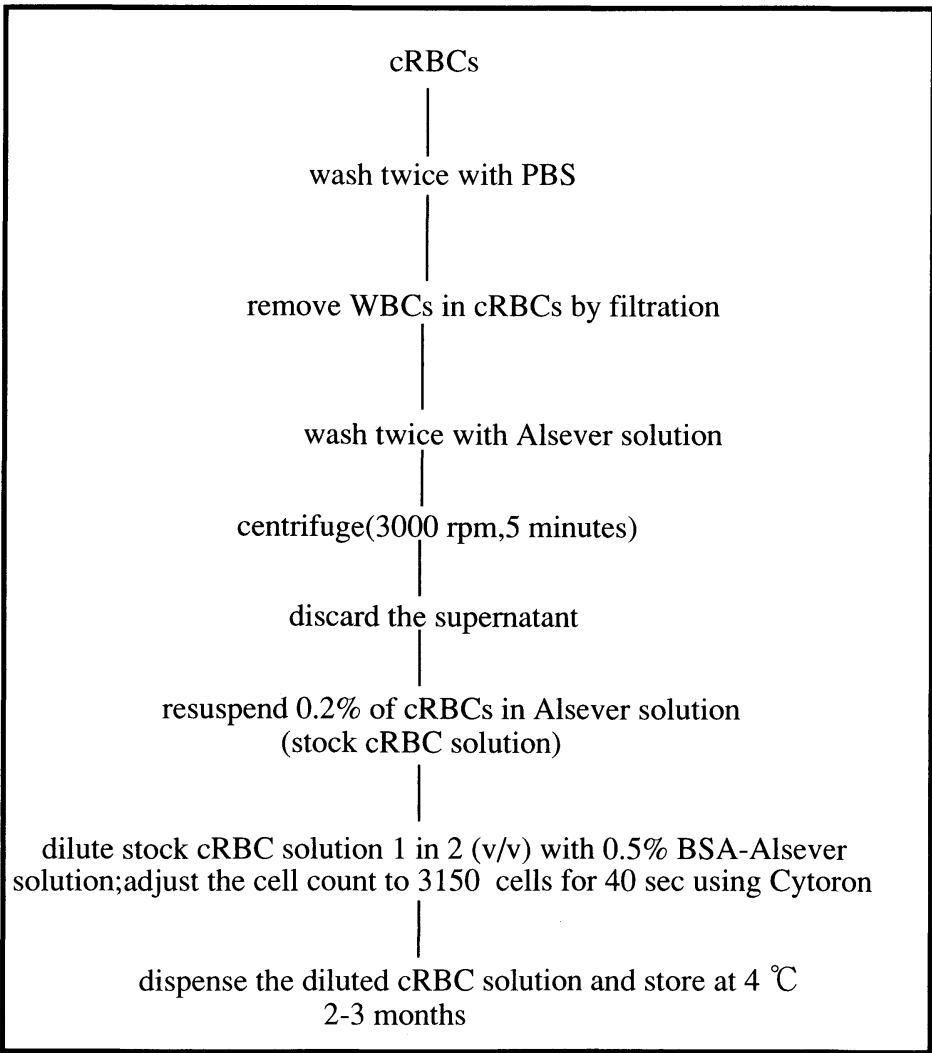

Fig. 1 Procedure for preparing cRBCs for use as internal control for counting WBCs. 


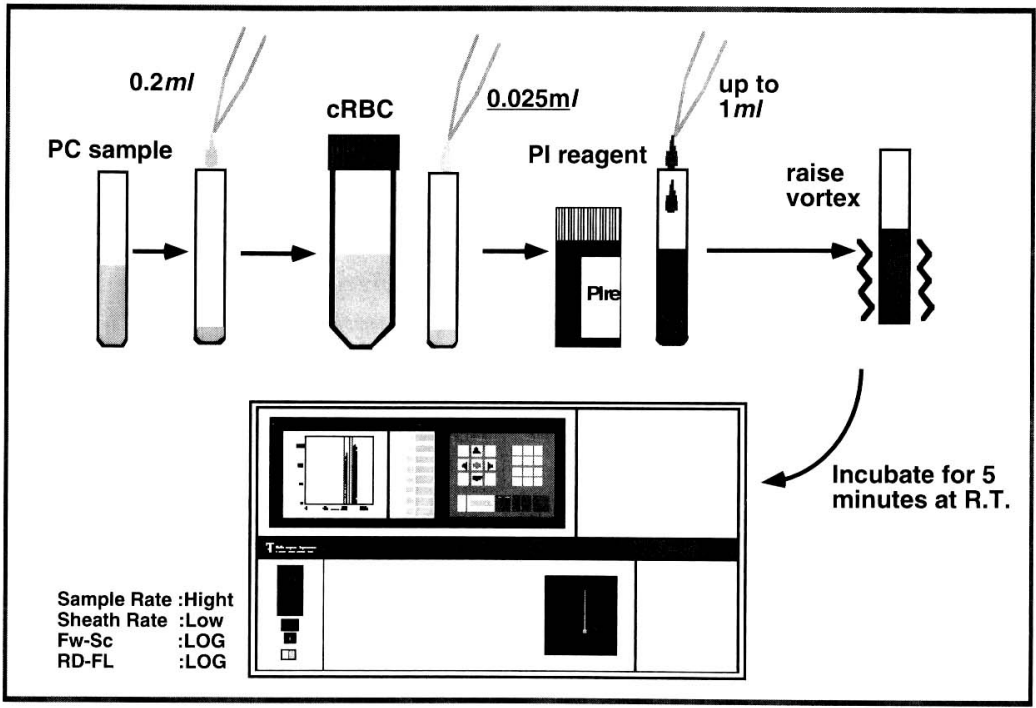

Fig. 2 Procedure for PI staining and FCM method. The cRBC reagent is adjusted to 3150 cells per $\mathrm{m} l$.

(a)

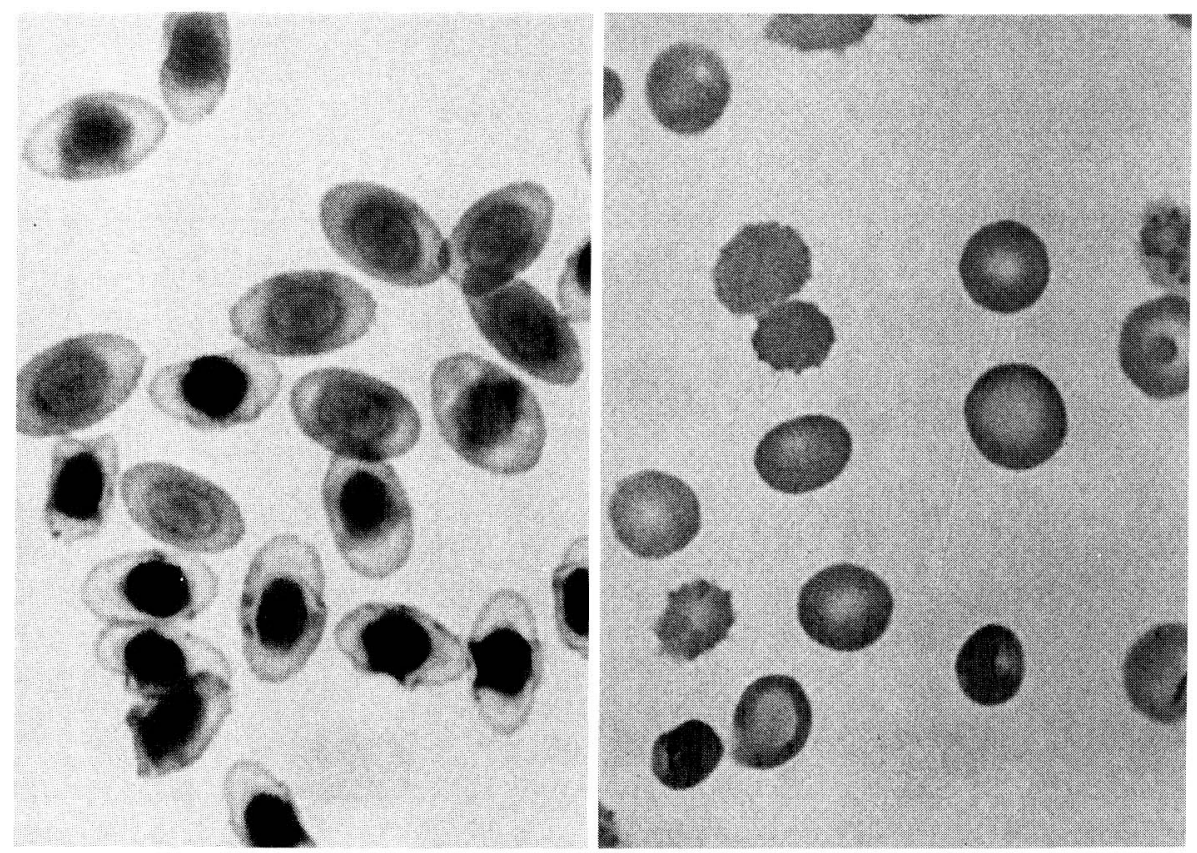

Fig. 3 Wright's/ Giemsa staining of cRBCs (a) and human RBCs (b). 
(Sigma) with $99 \mathrm{~m} l$ of distilled water.

Preparation of cRBCs:

cRBCs were purchased from Nippon BioSupp. Center K.K. and prepared as described in Fig. 1. In brief, the cRBCs were washed with phosphate buffered saline (PBS). Contaminating WBCs were removed by filtration (Pall PL50) and the cRBCs were washed again with

a

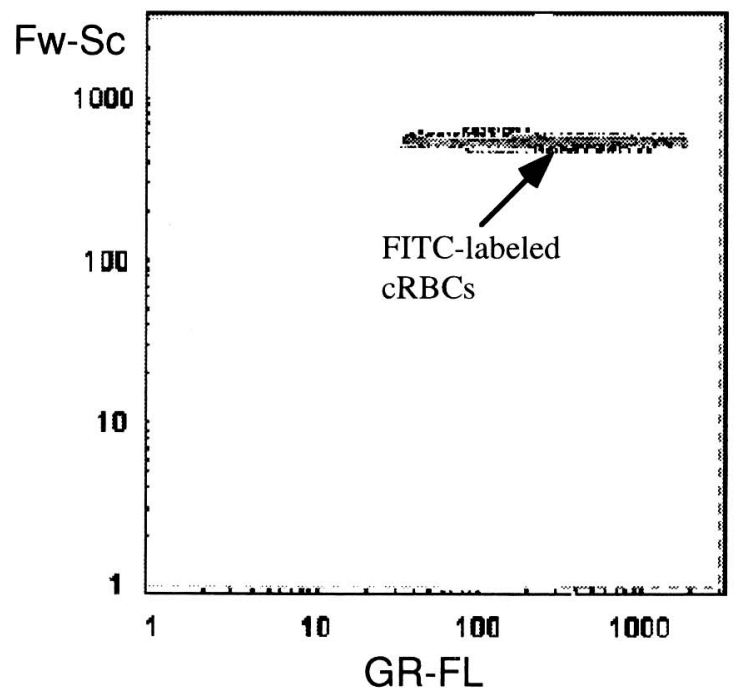

b

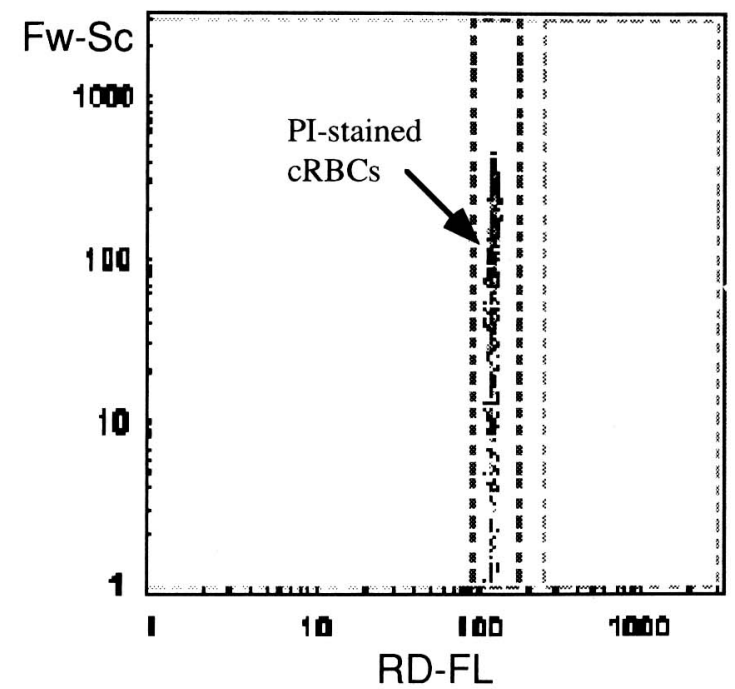

Alsever's solution. The cells were them centrifuged at $3,000 \mathrm{rpm}$ for 5 minutes, the supernatant was discarded and the packed cRBCs were resuspended to $0.2 \%$ in Alsever's solution. This cRBC suspension was then diluted 1 in $2(\mathrm{v} / \mathrm{v})$ with $0.5 \%$ bovine serum albumin (BSA)-Alsever's solution. This sample could be stored for 3 months in good condition. If stored

C

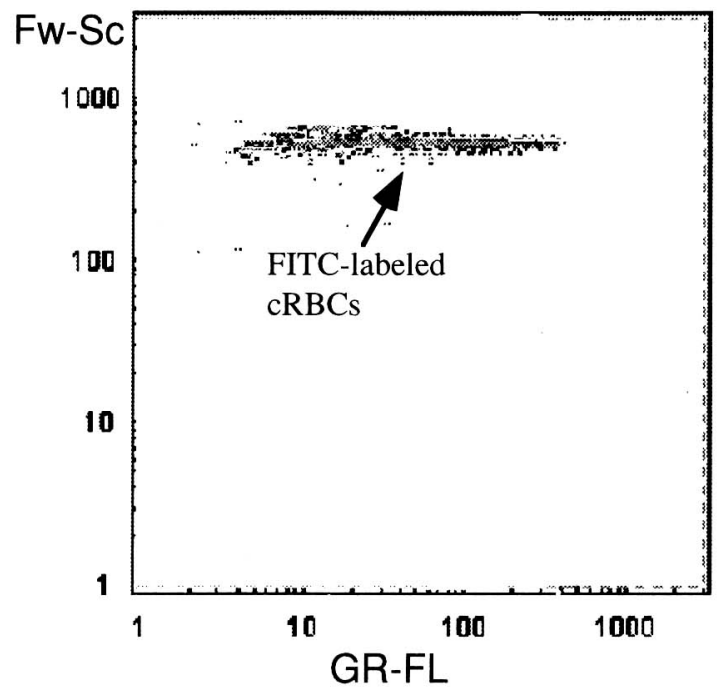

d

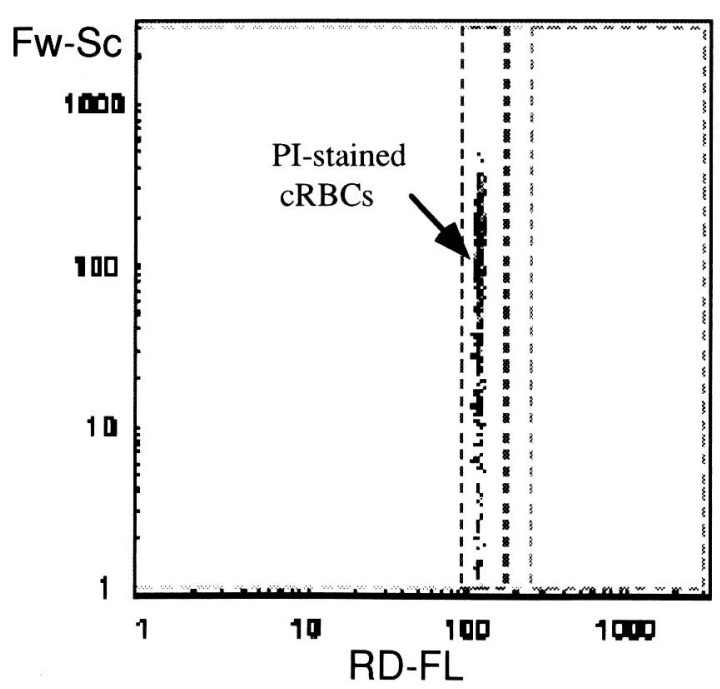

Fig. 4 Cytograms of FITC-labeled cRBC and cRBC stained with PI reagent. Freshly prepared FITC-labeled cRBCs (a), freshly prepared cRBCs stained with PI reagent (b), and after 10 days storage $(c, d)$. 
more than 3 months, however, the cRBCs began to lyse. The cRBCs were adjusted to $4.0 \times 10^{6}$ per $\mathrm{m} l$ using a Nageotte hemocytometer. The cRBCs were stained with PI reagent and the flow rate of Cytoron was adjusted to 3,150 cells for 40 seconds' counting. This cRBC suspension was dispensed into tubes and stored at $4^{\circ} \mathrm{C}$.

PI-staining and FCM method:

Fig. 2 shows the protocol for testing a PC sample. $0.2 \mathrm{~m} l$ of $\mathrm{PC}$ sample and $0.025 \mathrm{~m} l$ of cRBCs were added to a tube and the tube was filled with PI reagent to a volume of $1 \mathrm{ml}$. The Cytoron (Orgho-Clinical Diagnostics K.K., Tokyo, Japan) was used for FCM counting, with calibration each day using control beads (Orgho-Count Calibration Kit) to verity the flow rate and calculate the reaction mixtures. The Cytoron was set so that measuring time using the control beads was 40 seconds (The best coefficient of variation value was 40 seconds). $0.025 \mathrm{ml}$ of the unlabeled $\mathrm{cRBC}$ suspension stained with PI reagent was adjusted to 3,150 cells for 40 seconds using the Cytoron.

Counting with the Nageotte hemocytometer:

Samples were diluted 1 in $5(\mathrm{v} / \mathrm{v})$ with Türk solution. $0.05 \mathrm{~m} l$ was loaded into the Nageotte chamber and the total number of WBCs was

(a)

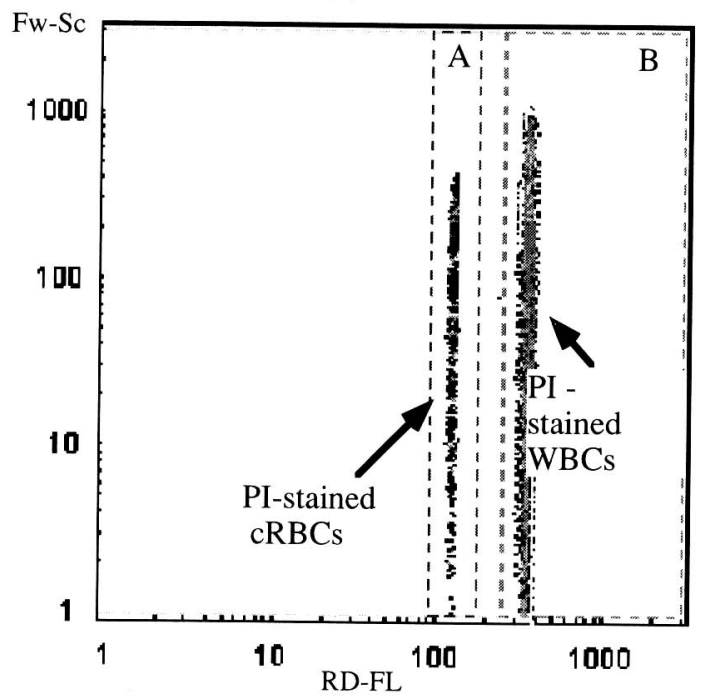

Table 1 Reproducibility of test results using the Cytoron

\begin{tabular}{c|c}
\hline No. & $\begin{array}{c}\text { Number of } \begin{array}{c}W B C s \text { in } P C \\
\left(\times 10^{3} \text { cells } / \mathrm{m} l\right)\end{array} \\
6860\end{array}$ \\
6278 & $0.88 \pm 0.35$ \\
6571 & $0.88 \pm 0.35$ \\
1476 & $1.25 \pm 0.46$ \\
1478 & $2.88 \pm 0.35$ \\
3781 & $1.63 \pm 0.52$ \\
7598 & $15.3 \pm 0.89$ \\
2414 & $64.5 \pm 0.93$ \\
2514 & $108.0 \pm 1.16$ \\
\hline \multicolumn{2}{c}{$207.0 \pm 7.29$} \\
\hline
\end{tabular}

counted.

\section{Results}

Wright's/Giemsa staining of the nuclei:

Fig. 3 shows cRBCs stained with Wright's/ Giemsa. Wright's-stained nuclei of cRBCs are illustrated.

FCM analysis of the cRBCs and contaminating WBCs:

Cytograms of FITC-labeled $\mathrm{cRBCs}^{5)}$ and PI-stained cRBCs are shown in Fig. 4. Fig. 4a shows an analysis of freshly prepared FITC-

(b)

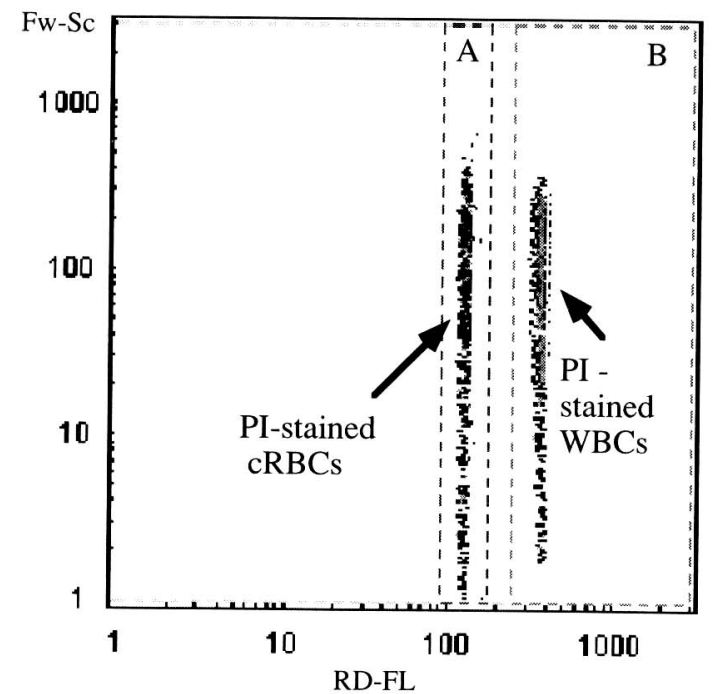

Fig. 5 FCM cytogram of PI-stained cRBCs and human WBCs using freshly prepared cRBCs (a) and cRBCs stored for three months (b). 


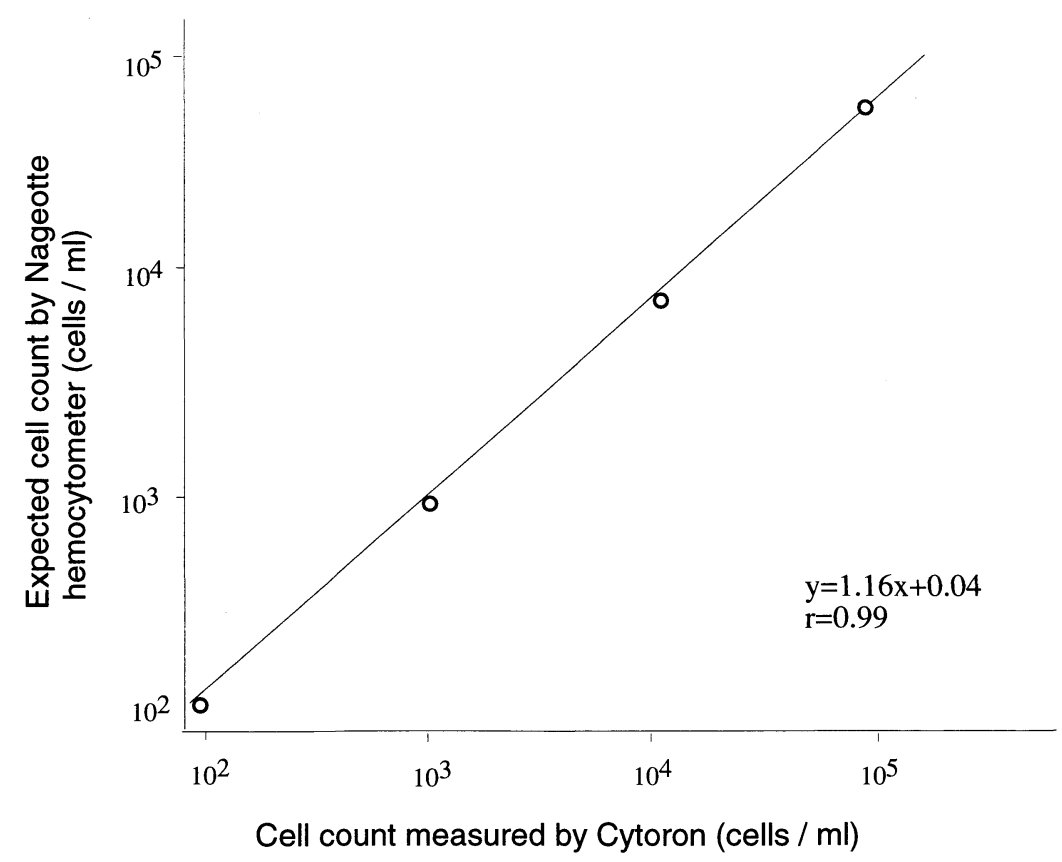

Fig. 6 Standard curve for counting dilutions of low WBC concentrations.

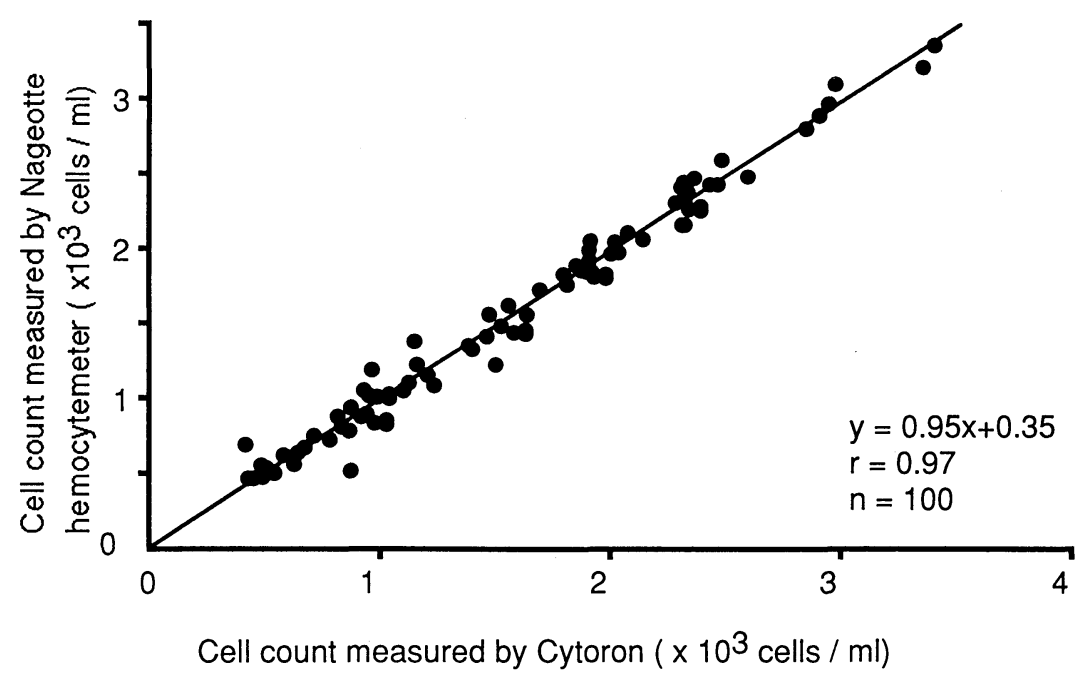

Fig. 7 Correlation between measurement of WBCs by Cytoron and the expected cell counts using a Nageotte hemocytometer.

labeled cRBCs while Fig. 4b shows freshly prepared cRBCs. Ten days later, the intensity of the FITC-labelled cRBC was decreased (Fig. 4c), but that of the cRBCs stained with PI was stable (Fig. 4d).

In contrast, Fig. 5 shows cytograms using our modified method in which both cRBCs and contaminating WBCs were stained with PI reagent. Cytograms of freshly prepared $\mathrm{cRBCs}$ (a) and 3-month-old cRBCs (b) showed a clear separation between cRBCs and the contaminating WBCs. The cRBCs were stable for 3 months 
(1)

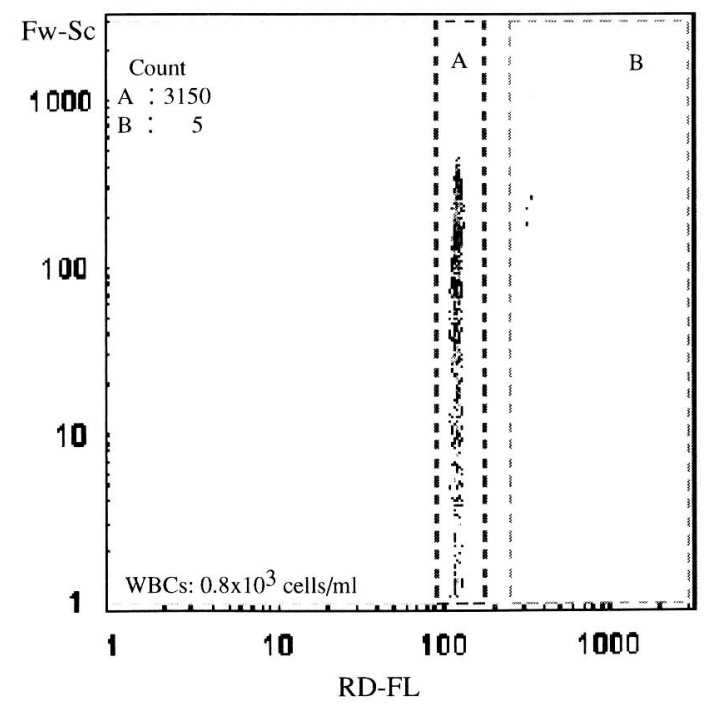

(2)

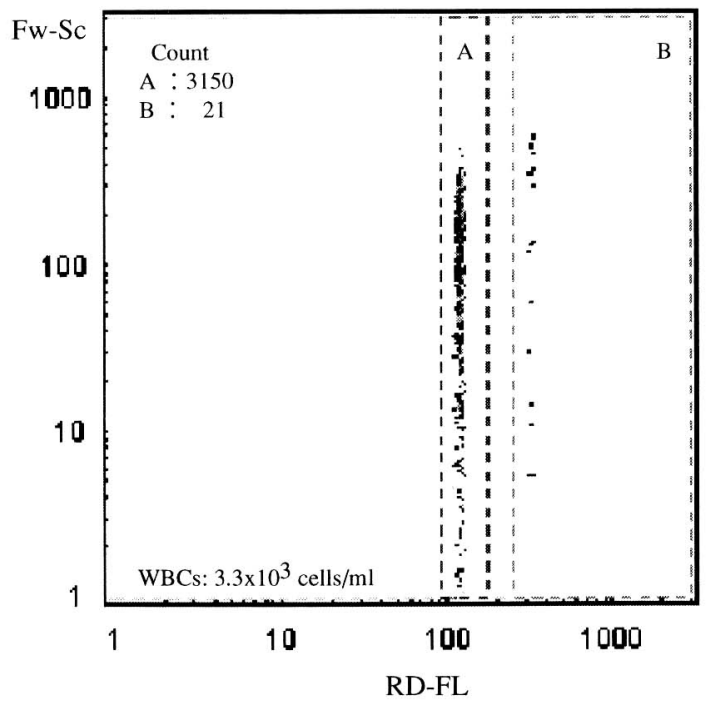

Fig. 8 Cytogram and number of PI-stained cells in PCs prepared with a Cobe Spectra (1) and the CS3000 plus (2). The number of WBC nuclei (A) and that of $\mathrm{cRBC}(\mathrm{B})$ are counted. Thus,

$\frac{\text { Number of } \mathrm{B}}{\text { Number of } \mathrm{A}} \times\left(\frac{4 \times 10^{6} \times 0.025}{0.2}\right) \times 10^{3}$ cells $/ \mathrm{m} l$

$0.025 \mathrm{~m} l$ of $\mathrm{cRBCs}\left(4 \times 10^{6}\right.$ cells $\left./ \mathrm{m} l\right)$ and $0.2 \mathrm{~m} l$ of sample were added to a total volume of $1 \mathrm{~m} l$ of reaction mixture.

Table 2 Measurement of WBCs (a) before filtration and (b) after filtration by the two methods

\begin{tabular}{c|c|c|c|c}
\hline \multirow{2}{*}{$\begin{array}{c}\text { Experiment } \\
\text { no. }\end{array}$} & \multicolumn{3}{|c}{ Measurement $\left(\times 10^{3}\right.$ cells $\left./ \mathrm{m} l\right)$} \\
\cline { 2 - 5 } & $\begin{array}{c}\text { Hemocytometer } \\
\text { Cell number }\end{array}$ & \multicolumn{2}{c}{$\begin{array}{c}\text { Flowcytometer } \\
\text { Cell number }\end{array}$} \\
\cline { 2 - 5 } & (a) & (b) & (a) & (b) \\
\hline 6533 & $870 \pm 30$ & N.D. & $929 \pm 10$ & $0.2 \pm 0.1$ \\
5755 & $210 \pm 18$ & N.D. & $225 \pm 7$ & $1.0 \pm 0.2$ \\
5771 & $150 \pm 12$ & N.D. & $186 \pm 8$ & $0.2 \pm 0.1$ \\
6175 & $150 \pm 13$ & N.D. & $160 \pm 9$ & $0.7 \pm 0.2$ \\
4326 & $200 \pm 17$ & N.D. & $223 \pm 10$ & $0.5 \pm 0.2$ \\
\hline \multicolumn{4}{c}{ N.D. : not detected Mean \pm 1 S.D. $(\mathrm{n}=4)$}
\end{tabular}

in $0.5 \%$ BSA-Alsever's and could be used as an indicator of control cells in this FCM method. Reproducibility of test and serial dilutions:

Reproducibility of test results by this method with the Cytoron are shown in Table 1. PIstained WBCs in $0.2 \mathrm{~m} l$ samples of 9 PCs were counted 8 times using the Cytoron. The results revealed good reproducibility.

A representative standard curve is shown in
Fig. 6. A sample of $1 \times 10^{5}$ WBCs per $\mathrm{m} l$ counted by the hemocytometer method was used. Serial dilutions (1 in 10) of samples in PBS were prepared and counted by the Cytoron and Nageotte hemocytometer techniques in parallel. As shown in Fig. 6, the test results of the assay were linear when plotted on a logarithmic scale from 1,000 to $100,000 \mathrm{WBCs}$ per $\mathrm{m} l$.

Correlation between the Cytoron and Nageotte hemocytometer methods:

Fig. 7 shows the correlation between cell numbers counted by the Cytoron and Nageotte hemocytometer methods in the range below $5 \times 10^{3}$ WBCs per $\mathrm{m} l$. From the slope of the line obtained, measurements by the hemocytometer method were about $10-20 \%$ less than those by FCM.

Number of WBCs in PCs samples:

The cytograms and number of WBCs in PCs samples from normal donors prepared by the Cobe Spectra (1) and the CS-3000 plus (2) are shown in Fig. 8. The samples had very low levels of residual WBCs. 
Before and after filtration:

Table 2 shows measurements of WBCs by the two methods both before (a) and after (b) filtration using a Pall PL50 filter. The FCM method detected all nucleated cells, whereas the Nageotte hemocytometer method was unable to detect all cells.

\section{Discussion}

As the technology for preparation of WBCreduced $\mathrm{PCs}$ has advanced, a need has developed for a method to measure very small numbers of contaminating WBCs in these PCs.

The traditional hemocytometer method was improved by staining the WBCs with Türk solution. Recently, a number of authors have described another counting method using FCM. Dzik et $\mathrm{al}^{1)}$ reported a method that analyzed the number of WBCs in samples from PCs using the combination of green and red fluorescence dyes on the FACS can (Becton-Dickinson, Mountsain View, CA, USA). Takahashi et $\mathrm{al}^{3)}$ obtained a sensitivity of $1.77 \times 10^{2}$ cells per $\mathrm{m} l$ without an internal indicator using the Cytoron Absolute (new model of Cytoron, Ortho-Clinical Diagnostics K.K. Tokyo, Japan). The Cytoron Absolute can define the number of cells in the flow cell. The older model Cytoron used in this study does not have this capacity. Instead, cRBCs were used as the internal indicator of the number of cells per flow cell.

Wen $z$ et $\mathrm{al}^{4)}$ reported a sensitivity of 0.02 cells per $\mu l$. Their method required analysis of the total volume in the sample tubes, including the addition of extra buffer to flush the sidewalles of the tubes to ensure that all cells entered the flow stream. The average time needed was 20 minutes including staining with PI reagent and measurement using an Epics apparatus (Coulter Diagnostics). In addition, the risk of introducing air bubbles into the flow cells was great.

Vachula et $\mathrm{al}^{5)}$ reported a method using a known number of FITC-labeled cRBCs as an indicator of the number of cells analyzed and counted WBCs in samples from PCs using this dual stain with the FACScan instrument.

We have modified their method to eliminate the FITC stain because it is unstable and decreases in intensity over time. We used PI reagent to stain the nucleus of the $\mathrm{cRBCs}$. It was also found that the large nuclei of cRBCs are more sensitive to staining with PI reagent than FITC reagent (Fig. 3A).

The characteristics of the method described here are as follows: the number of contaminating WBCs ranged from $1.6 \times 10^{2}-10^{5}$ cells per $\mathrm{m} l$; reproducibility test results were good; and the average time needed for counting was 40 seconds. Further, the method is based on a single stain using PI reagent for the nucleus of both human WBCs and cRBCs.

These results show that this modified method for counting residual WBCs in PCs is sensitive, accurate, rapid and simple for routine use.

\section{Conclusion}

This method counts residual WBCs in PC samples of $0.2 \mathrm{~m} l$. The method is rapid and easy to perform.

We consider this method to be useful for the quality control of PCs in routine testing.

\section{References}

1) Dzik WH, Ragosta A, Cusack WF: Flow-cytometric method for counting very low numbers of leukocytes in platelet products. Vox Sang., 59(3): 153-159, 1990.

2) Sheckler VL, Loken MR: Routine quantification of white cells as low as 0.001 per $\mu \mathrm{L}$ in platelet components. Transfusion, 33(3): 256-261, 1993.

3) Takahashi T, Hosoda M, Sekiguchi S: A flow cytometric method to detect residual leukocytes in platelet and red cell concentrates. J. Jr. Trans. Medicine, 36(3): 429-437, 1990.

4) Wenz B, Burns ER, Lee V, Miller WK: A rare-event analysis model for quantifying white cells in white cell-depleted blood. Transfusion, 31(2): 156-159, 1991.

5) Vachula M, Simpson SJ, Martinson JA, Aono FM, Hutchcraft AM, Balma DL, Van Epps DE: A flow cytometric method for counting very low levels of white cells in blood and blood components. Transfusion, 33(3): 262-267, 1993. 